\title{
Hydrology laboratory research modeling system (HL-RMS) of the US national weather service
}

\author{
Victor Koren*, Seann Reed, Michael Smith, Ziya Zhang, Dong-Jun Seo \\ Office of Hydrological Development, National Weather Service, NOAA, 1325 East-West Highway, Silver Spring, MD 20910, USA
}

Accepted 23 December 2003

\begin{abstract}
This study investigates an approach that combines physically-based and conceptual model features in two stages of distributed modeling: model structure development and estimation of spatially variable parameters. The approach adds more practicality to the process of model parameterization, and facilitates an easier transition from current lumped model-based operational systems to more powerful distributed systems. This combination of physically-based and conceptual model features is implemented within the Hydrology Laboratory Research Modeling System (HL-RMS). HL-RMS consists of a well-tested conceptual water balance model applied on a regular spatial grid linked to physically-based kinematic hillslope and channel routing models. Parameter estimation procedures that combine spatially distributed and 'integrated' basin-outlet properties have been developed for the water balance and routing components. High-resolution radar-based precipitation data over a large region are used in testing HL-RMS. Initial tests show that HL-RMS yields results comparable to well-calibrated lumped model simulations in several headwater basins, and it outperforms a lumped model in basins where spatial rainfall variability effects are significant. It is important to note that simulations for two nested basins (not calibrated directly, but parameters from the calibration of the parent basin were applied instead) outperformed lumped simulations even more consistently, which means that HL-RMS has the potential to improve the accuracy and resolution of river runoff forecasts.

Published by Elsevier B.V.
\end{abstract}

Keywords: Distributed model; Conceptual model; Water balance; Kinematic routing; Parameter estimation; Radar

\section{Introduction}

Accounting for spatial variability of basin physiographic properties as well as meteorological forcing such as precipitation and temperature through distributed hydrologic modeling continues to be a very active area of research and development in hydrology. The growing availability of radar-based precipitation

\footnotetext{
* Corresponding author.

E-mail address: victor.koren@noaa.gov (V. Koren).
}

estimates (Seo and Breidenbach, 2002; Young et al., 2000) and other sets of spatial data has intensified this line of research in recent years. To the US National Weather Service (NWS), distributed modeling is of particular interest and significance in that, among other benefits, it may allow streamflow prediction at interior locations of the basin where no streamflow observations exist, and hence can potentially revolutionize operational flood forecasting.

The literature reports numerous distributed models and modeling approaches that address a wide variety 
of issues. They range in complexity from the so-called 'physically based fully distributed' (Wigmosta et al., 1994; Abbott et al., 1986; Garrote and Bras, 1995; Julien et al., 1995) to 'semi-distributed' (Boyle et al., 2001; Obled et al., 1994; Schumann, 1993), and to conceptual lumped rainfall-runoff models applied at smaller scales (Michaud and Sorooshian, 1994; White, 1988). In terms of computational elements, they may be built on grid (Ogden and Julien, 1994; Kouwen and Garland, 1989), small sub-basins (Carpenter et al., 2001; Obled et al., 1994), triangulated irregular network (TIN) (Goodrich et al., 1991) and stream tubes (Grayson et al., 1992; Moore and Grayson, 1991). Recently, efforts have been undertaken to account for the effects of 'sub-grid' heterogeneity on hydrologic processes (Koren et al., 1999; Beven, 1995).

In spite of the more prevalent use of physical equations and the use of finer resolution data, the emerging picture, however, is that the use of more complex models does not necessarily result in better hydrograph simulation at the basin outlet. The current sentiment on distributed modeling is perhaps best summarized by Seyfried and Wilcox (1995):

One of the disadvantages of physically based models is that they require very much more input information than their more empirical, lumpedparameter counterparts. Thus, parameterization and validation become major tasks. Despite the much greater effort required to parameterize, validate, and run physically based models, simulated results often provide only slightly better or even worse correspondence with measured values than lumped-parameter models (Beven, 1989; Loague, 1990; Wilcox et al., 1990; Grayson et al., 1992). This has prompted many to question whether physically based models are worth the effort, at least outside strictly research applications...

The model comparisons of Neuf (1981), Loague and Freeze (1985), Michaud and Sorooshian (1994), and Loague (1990) also support this sentiment.

The literature identifies scale and parameter estimation as the two biggest hurdles to overcome in distributed modeling. Most distributed models are based on point process equations which may poorly represent watershed scale processes because of vertical and horizontal heterogeneities of basin properties. In theory, parameters of physically based models can be measured or calculated based on direct measurements of physical quantities. However, in practice, physically based model parameters cannot be determined from measurable physical quantities because of the non-linearities and structural heterogeneities of hydrological systems (Beven, 1995). This leads to the necessity of calibrating the so-called 'effective' parameters at the grid scale to generate reasonable results at the watershed scale. The calibration procedure becomes more complicated because effective parameters represent local properties, and they are less identifiable than lumped parameters from hydrograph analysis. When parameter values are adjusted to calibrate a model, one must question if there is still a physical significance to the parameter estimates or if at this point the physically-based model has reverted to a type of elegant black box (Loague, 1990). In response to these concerns, a number of critiques and discussions of physically-based models have appeared in the recent literature. For physically-based models, parameter error may result from the inability to represent areal distributions on the basis of point measurements (Loague and Freeze, 1985). Beven (1989) continued this critical series by concluding that current physically-based models are not really based on physics. Woolhiser (1996) elaborated on this sentiment in the context of the two classes of criticisms of physically based models. He stated that if the models have a true physical basis, then modelers should be able to estimate the parameters a priori or measure them in the field.

While there are questions about the level of complexity justified in hydrologic models and the degree to which parameterizations can be physicallybased as described above, there are also indications that some degree of basin discretization and the use of radar-based products can nevertheless improve simulation accuracy. For example, Michaud and Sorooshian (1994) found that a complex distributed model calibrated at the basin outlet was able to generate simulations at eight internal points that were at least as accurate as the outlet simulations. These results underscore one of the main advantages of distributed parameter hydrologic modeling: the ability 
to predict hydrologic variables at interior points. They also concluded that a simple distributed model proved to be just as accurate as a complex distributed model given that both were calibrated and noted that model complexity does not necessarily lead to improved simulation accuracy. However, parameterization problems and data uncertainties can eliminate benefits of the semi-distributed approach when applied to mid/ large $\left(300-3000 \mathrm{~km}^{2}\right)$ basins having significant damping effects.

In light of these recent modeling trends and issues, we argue that what is needed is to reconsider the use of simpler approaches, as expressed by Robinson and Sivapalan (1995):

...work towards finding connections between the physically based and conceptual models has been inadequate, although this is precisely what is required for the advancement of hydrological modeling for predictive purposes.

We believe that lumped models and lumped modeling experience are yet to be fully exploited in distributed modeling, and that comprehensive comparative analysis of conceptual lumped and physically-based distributed models is needed to derive full benefit from them. Note that, while most conceptual lumped models do not explicitly use the classical equations of mass and momentum conservation, they do incorporate fundamental physical concepts supported by field experiments. As such, over the range of scales where conceptual models do work well, they may serve as building blocks for distributed modeling systems.

The purpose of this paper is to describe an approach that combines lumped conceptual and distributed model features in the development and parameterization of a modeling system referred to as the Hydrology Laboratory Research Modeling System (HL-RMS). HL-RMS provides a modeling framework in which lumped, semi-distributed, and fully distributed approaches may be constructed and tested. Currently, HL-RMS consists of a well-tested conceptual water balance model applied on a regular spatial grid and physically based kinematic hillslope and channel routing models. A parameter estimation procedure is being developed that combines analyses of distributed basin properties and an integrated basin response at a gaged outlet. While the discussion of the model and results will be at the broad scientific level, particular emphasis will be placed on science and application issues facing the NWS in its river and flash flood forecasting mission.

\section{Hydrology laboratory research modeling system (HL-RMS) description}

\subsection{System structure}

HL-RMS is a flexible modeling system, able to use grid cells or sub-basins as the computational elements for rainfall-runoff modeling. Currently, HL-RMS is defined on a regular rectangular grid as shown in Fig. 1a. Each grid cell consists of a water balance component and a hillslope and channel routing component. A number of conceptual hillslopes are defined to make overland flow distances physically realistic for the relatively large $\left(\sim 16 \mathrm{~km}^{2}\right)$ cell size. A drainage density parameter is used to subdivide a cell into equally sized overland flow planes as seen in Fig. 1b. Conceptual hillslopes drain water to a conceptual channel within the same grid cell. A conceptual channel usually represents the highest order stream of a selected grid cell. It is assumed that all hillslopes have the same properties inside each grid cell but they may be different from cell to cell. The main channel length within each cell is assumed to be equal to a cell diagonal distance. Cell-to-cell channel routing is done using a flow direction grid like that illustrated in Fig. 1a. A modified version of the algorithm described by Wang et al. (2000) was developed to generate the flow direction grid. The algorithm automatically generates a coarser resolution flow direction grid from higher resolution DEM data. As a result, the basin boundaries and channel structure match reasonably well with high resolution basin properties (Fig. 1a). To facilitate efficient routing calculations, the drainage network depicted in Fig. 1a was translated into a computational sequence of grid cells in an upstream to downstream order. The same method for storing the computational grid sequence was used in the Nile Forecast System (Koren and Barrett, 1995).

Each grid cell consists of a water balance component and a hillslope and channel routing component. Fast response runoff from the water 
(a)

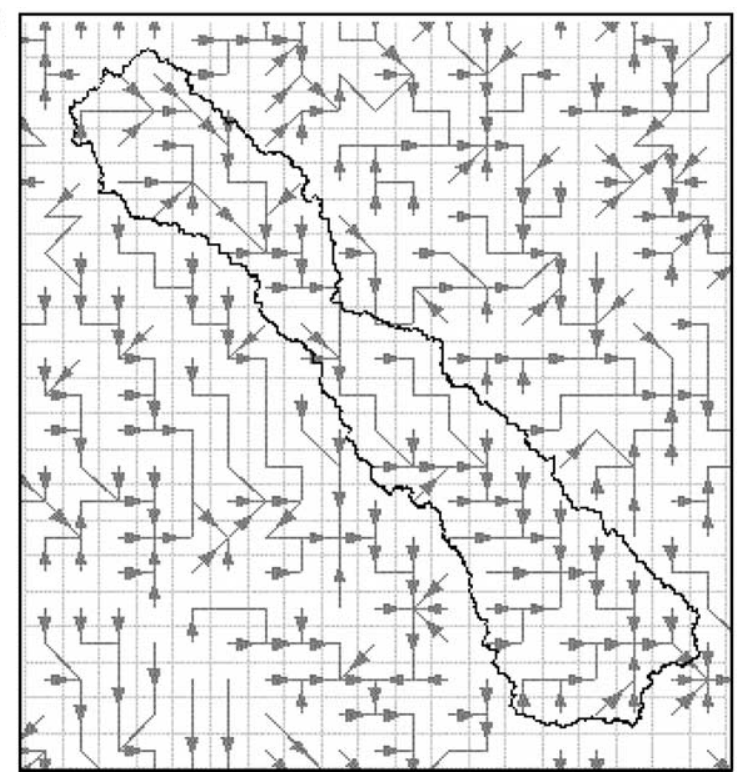

(b)

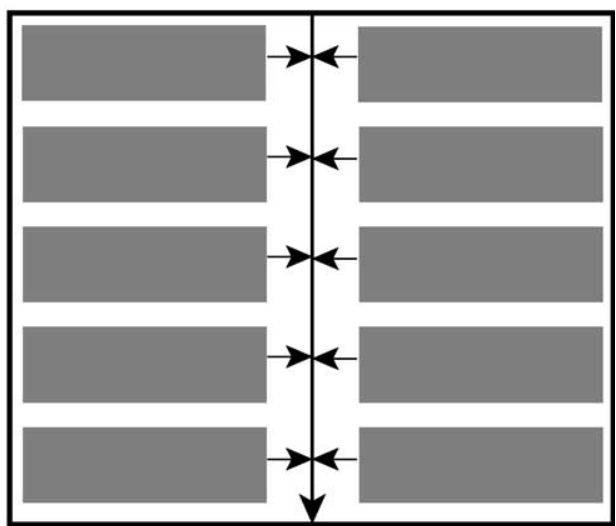

Fig. 1. Cell-to-cell drainage network (a), and conceptual hillslopes of a grid cell (b).

balance model is routed over conceptual hillslopes within each cell to a conceptual channel. Slow response runoff is assumed to enter the channel system directly from the soil, and therefore, bypass the hillslope routing. There is no physical connection between soil moisture states in adjacent grid cells. The conceptual channel is the only source of water exchange between neighboring pixels. While this may be considered a weakness in the current distributed system, some field data support this 'zero lateral conductivity' assumption (Watson et al., 1998).

The water balance component of the current version of the HL-RMS uses the Sacramento Soil Moisture Accounting Model (SAC-SMA), and hillslope-channel routing employs the kinematic wave model. Several factors played a role in this selection. Use of the SAC-SMA is a practical choice because NWS hydrologists have great experience with lumped applications of the model. Also, the work of Koren et al. (2000) established relationships between SACSMA parameters and soil properties, making it possible to run simulations using parameter estimates that vary within a basin.

The kinematic wave model is well tested, and it is successfully used in watershed modeling (Goodrich et al., 1991; Willgoose and Kuczera, 1995; Koren and Barrett, 1995; Bell and Moore, 1998; Georgakakos, 2002; Vieux and Moreda, 2003). Although accuracy of the kinematic model reduces in hydraulically mild slopes (Fread, 1993; Singh, 1996), it is appropriate to use it in the first version of the HL-RMS mainly for two reasons: (1) it will be used mostly for headwater basins where lateral inflow effects dominate over wave propagation effects, and (2) flood prediction (the main goal of the NWS) is the most critical in rather steep topography (e.g. most common terrain and channel slopes in study region were well above $10 \mathrm{ft} /$ $\mathrm{ml}$ ). Another consideration was the high computational efficiency and flexibility of this algorithm as demonstrated in its earlier application to the Nile basin (Koren and Barrett, 1995). We anticipate that in operational applications over large river basins the HL-RMS will be combined with a dynamic routing model which is now available in the NWS River Forecasting System (Sylvestre and Sylvestre, 2002).

\subsection{Water balance component}

The SAC-SMA is a conceptual model typically applied in a lumped mode to represent spatially heterogeneous runoff processes over river basins 
ranging from tens to a few thousand square kilometers. There are strong physical arguments and application results to support the model structure and algorithms. A detailed description of the model and its sketches can be found in Burnash (1995) and Duan et al. (2001). The basic design of the SAC-SMA centers on a two layer structure: a relatively thin upper layer, and usually a much thicker lower layer which supplies moisture to meet the evapotranspiration demands. Each layer consists of tension and free water storages that interact to generate soil moisture states and six runoff components. Fast response components include impervious, surface and direct runoff, and slower response components include interflow, supplemental and primary ground water runoff. The free water storage of the lower layer is divided into two sub-storages which control supplemental and primary ground water flows, respectively. Partitioning of rainfall, $P$, into surface runoff and infiltration is governed by the upper layer soil moisture deficit, $D_{\mathrm{uz}}$, and the percolation potential of the lower layer. It assumes a saturation-excess mechanism for the upper layer storages. No surface runoff occurs before the tension and free water capacities of the upper layer (the full saturation of the upper layer) is filled, other words the upper layer saturation demand is satisfied. After that, rainfallrunoff partitioning is similar to an infiltration-excess type mechanism, and surface runoff rate $R_{\mathrm{s}}$ becomes a function of percolation, $I_{\text {perc }}$ :

$R_{\mathrm{s}}= \begin{cases}P-I_{\mathrm{perc}}, & P>D_{\mathrm{uz}} \\ 0, & P \leq D_{\mathrm{uz}}\end{cases}$

The potential percolation rate is a non-linear function of the lower layer saturation, $\theta_{\mathrm{lzw}}$, and the upper layer free water saturation, $\theta_{\mathrm{uzf}}$ :

$I_{\mathrm{perc}}=\left[I_{0}+I_{\mathrm{max}} \cdot\left(1-\theta_{\mathrm{lzw}}\right)^{x}\right] \theta_{\mathrm{uzf}}$

where $I_{\max }$ is the maximum percolation rate under dry conditions, $I_{0}$ is the maximum percolation rate under saturated conditions, and is an exponent value that controls the shape of the percolation function at intermediate values of lower zone moisture content. Drainage from each free water is a linear function of its soil moisture content.

\subsection{Hillslope and channel routing component}

The kinematic wave approximations to the full continuity and momentum equations of overland flow were defined as

$\frac{\partial h}{\partial t}+L_{\mathrm{h}} \frac{\partial q}{\partial x}=R_{\mathrm{s}}, \quad 0 \leq x \leq L_{h}$

and

$q=\frac{2 D \sqrt{S_{\mathrm{h}}}}{n_{\mathrm{h}}} h^{5 / 3}=q_{\mathrm{s}} h^{5 / 3}$

where $h$ is an overland flow depth, $q$ is discharge per unit area of hillslope, $R_{\mathrm{s}}$ is a fast runoff from the water balance simulations, in $\mathrm{m} / \mathrm{s}, S_{\mathrm{h}}$ is a hillslope slope (dimensionless), $n_{\mathrm{h}}$ is a hillslope roughness coefficient, in $\mathrm{s} / \mathrm{m}^{1 / 3}, D$ is a drainage density parameter in $\mathrm{m}^{-1}, L_{\mathrm{h}}=1 /(2 D)$ is a hillslope length, $t$ is time, and $x$ is the distance along the hillslope. Parameter $q_{\mathrm{s}}$ is expressed in $\mathrm{s}^{-1} \mathrm{~m}^{-2 / 3}$. Overland flow characteristics $S_{\mathrm{h}}, n_{\mathrm{h}}$, and $D$ have to be defined for each grid cell. A boundary condition of zero flow was assumed at hillslope ridges.

Similar kinematic wave equations were used for the channel routing at each grid cell:

$\frac{\partial A}{\partial t}+\frac{\partial Q}{\partial x}=\left(q_{L_{\mathrm{h}}}+R_{\mathrm{g}}\right) \frac{f_{\mathrm{c}}}{L_{\mathrm{c}}}, \quad 0 \leq x \leq L_{\mathrm{c}}$

and

$Q=Q_{\mathrm{s}} A^{m}$

where channel cross-section, $A$, and discharge, $Q$, can vary from cell to cell and within each cell, the righthand side term of Eq. (5) is a lateral inflow per unit length of channel, $q_{L_{\mathrm{h}}}$ is routed overland flow rate at the hillslope outlet, $R_{\mathrm{g}}$ is a slow runoff component from the water balance simulations, $f_{\mathrm{c}}$ is a grid cell area, $L_{\mathrm{c}}$ is a channel length within a cell, $m$ is an exponent parameter, and $Q_{\mathrm{s}}$ is a parameter (referred as a specific discharge) which is expressed in $\mathrm{m}^{3} / \mathrm{s} / \mathrm{m}^{2 m}$. A physical meaning of the specific discharge will be discussed in Section 3. The upper boundary condition at each grid cell $(x=0)$ is the total discharge from all grid cells draining into the current cell. A fairly general finite-difference scheme (Smith, 1980) employing weighting factors $\alpha$ and $\beta$ in the spatial 
and temporal dimensions was used in this study:

$$
\begin{aligned}
\frac{\partial Y}{\partial t}= & \frac{1}{\Delta t}\left[\alpha\left(Y_{i, j+1}-Y_{i, j}\right)\right. \\
& \left.+(1-\alpha)\left(Y_{i+1, j+1}-Y_{i+1, j}\right)\right] \\
\frac{\partial Y}{\partial x}= & \frac{1}{\Delta x}\left[\beta\left(Y_{i+1, j_{+1}}-Y_{i, j+1}\right)\right. \\
& \left.+(1-\beta)\left(Y_{i+1, j}-Y_{i, j}\right)\right]
\end{aligned}
$$

where subscripts $i$ and $j$ refer, respectively, to distance and time, $\Delta x$ and $\Delta t$ are the spatial and temporal increments, and $Y$ is a variable under consideration. Weighting factors lie within the interval $0 \leq \alpha, \beta \leq 1$. In the case of $\beta \neq 0$, the resulting equations become non-linear, and Newton's iteration method (Chow et al., 1988) was applied. The numerical stability of the scheme depends strongly on the ratio of time-space weighting factors (Smith, 1980):

$$
\frac{\alpha}{\beta} \leq C r \leq \frac{1-\alpha}{1-\beta}
$$

where the Courant number, $\mathrm{Cr}$, can be defined as $c \Delta t / \Delta x$, in which $c$ is the wave celerity for the kinematic approximation. The scheme is unconditionally stable only for values $\alpha=0$ and $\beta=1$. These values of the weighting parameters are best for our needs because HL-RMS will be applied over a wide range of channel hydraulic conditions where it will be difficult to keep track of all possible restrictions on the Courant number during run time. The strength of the scheme is that as $\alpha$ and $\beta$ depart from the value of 0.5 , first order truncation errors increase independently of the ratio $\Delta x / \Delta t$.

\section{HL-RMS parameterization using DEM-GIS data}

Water balance and routing model parameters are assumed to be constant within each grid cell, however, they can vary from cell to cell. Thus, spatially variable parameter grids should be generated over the area of interest. The approach adopted here is a two-step procedure: derivation of a priori parameter grids, and adjusting of these grids using observed outlet hydrographs. Derivation of a priori parameter grids is a critical step to guarantee the success from a parameter adjusting step based on a basin response. Rinaldo et al. (1995) found that the inverse procedure of obtaining the local basin properties (in their case basin width function) from the basin response is not reliable. Therefore, reasonable spatial parameter patterns should be defined independently from basin properties. The basic idea used in this study is to combine distributed grid cell data (e.g. slope, soil properties) with integrated basin properties observed at the outlet (e.g. rating curve data). While this idea was applied in the first step of the routing parameter estimation procedure, it was used only in the second step of water balance model parameterization.

\subsection{Estimation of SAC-SMA parameters based on soil data}

Although there are strong physical arguments to support the SAC-SMA model, its 16 parameters (Table 1) cannot be measured directly. Manual and automatic procedures to estimate SAC-SMA parameters for lumped model applications are well defined (Burnash, 1995; Smith et al., 2003; Boyle et al., 2000; Hogue et al., 2000). The procedures are based solely on input-output data analysis. Consequently, they do not provide any information on intrabasin parameter variability, which is desirable information for the implementation of a distributed model. To account for the spatial variability within basins, a priori SAC-SMA parameter grids developed by Koren et al. (2000) were used.

Koren et al. (2000) developed a set of equations to derive 11 major SAC-SMA parameters (these parameters are highlighted in Table 1) from soil texture, hydrological soil group, and soil depth. These equations were developed based on both physical reasoning and empirical relationships. The main assumption was that tension water storages of the SAC-SMA model were related to available soil water (difference between field capacity and wilting point), and that free water storages were related to gravitational soil water. Available soil water and gravitational soil water were derived from soil properties, which could be inferred from soil texture: porosity, field capacity, wilting point, and hydraulic conductivity. Using 1-km soil texture data estimated for 11 soil layers (Miller and White, 1999), Koren et al. 
Table 1

SAC-SMA model parameters and their feasible ranges

\begin{tabular}{|c|c|c|c|}
\hline No. & Parameter & Description & Ranges \\
\hline 1 & UZTWM & The upper layer tension water capacity (mm) & $10-300$ \\
\hline 2 & UZFWM & The upper layer free water capacity (mm) & $5-150$ \\
\hline 3 & $\mathrm{UZK}$ & $\begin{array}{l}\text { Interflow depletion rate from the upper layer free water storage } \\
\left(\text { day }^{-1}\right)\end{array}$ & $0.10-0.75$ \\
\hline 4 & ZPERC & Ratio of maximum and minimum percolation rates & $5-350$ \\
\hline 5 & REXP & Shape parameter of the percolation curve & $1-5$ \\
\hline 6 & LZTWM & The lower layer tension water capacity (mm) & $10-500$ \\
\hline 7 & LZFSM & The lower layer supplemental free water capacity (mm) & $5-400$ \\
\hline 8 & LZFPM & The lower layer primary free water capacity $(\mathrm{mm})$ & $10-1000$ \\
\hline 9 & LZSK & $\begin{array}{l}\text { Depletion rate of the lower layer supplemental free water storage } \\
\left(\text { day }^{-1}\right)\end{array}$ & $0.01-0.35$ \\
\hline 10 & LZPK & Depletion rate of the lower layer primary free water storage $\left(\right.$ day $\left.^{-1}\right)$ & $0.001-0.05$ \\
\hline 11 & PFREE & $\begin{array}{l}\text { Percolation fraction that goes directly to the lower layer free water } \\
\text { storages }\end{array}$ & $0.0-0.8$ \\
\hline 12 & PCTIM & Permanent impervious area fraction & \\
\hline 13 & ADIMP & $\begin{array}{l}\text { Maximum fraction of an additional impervious area due to } \\
\text { saturation }\end{array}$ & \\
\hline 14 & RIVA & Riparian vegetation area fraction & \\
\hline 15 & SIDE & Ratio of deep percolation from lower layer free water storages & \\
\hline 16 & RSERV & $\begin{array}{l}\text { Fraction of lower layer free water not transferrable to lower layer } \\
\text { tension water }\end{array}$ & \\
\hline
\end{tabular}

(2000) generated a priori SAC-SMA parameter grids covering the conterminous US.

Results from lumped simulations using basinaveraged a priori parameters (Koren et al., 2000; Duan et al., 2001; Koren et al., 2003) suggest that a priori estimates are reasonable initial values for manual or automatic calibrations.

\subsection{Estimation of routing parameters using DEM and channel hydraulic data}

\subsubsection{Hillslope routing parameters}

As follows from Eqs. (3) and (4), three parameters are defined for overland flow routing: hillslope slope, roughness, and drainage density (or hillslope length if available). Note that in current model structure, hillslope slope and roughness may vary from cell to cell, but not among the conceptual hillslopes within a cell. Representative hillslope slopes are estimated from DEM data (30-m DEM data for basin scale applications, and 400-m DEM data for regional scale applications) by first computing the local slope of each DEM cell in the study domain, and then averaging all of the DEM cell slopes in each model cell (Reed et al., 2002). Spatially variable hillslope roughness values could be related to land use data based on a lookup table (Skahill and Johnson, 1999). However, a lookup table is very subjective, and it offers limited guidance in defining spatial variability because within a given land use category, published roughness values cover wide ranges of possible values that often overlap with the ranges assigned to other land use categories. Initial HL-RMS tests have shown more sensitivity to channel routing parameters than hillslope parameters; the tests also suggest that using spatially consistent hillslope roughness has been satisfactory. Therefore, in simulation runs presented here, a constant value of hillslope roughness (0.15) has been assigned for all model cells. This value is in the middle of lookup table ranges for agriculture and rangeland land use types which predominate in the basins being modeled.

For drainage density, Dingman (1993) notes that values ranging from 2 to $100 \mathrm{~km}^{-1}$ have been reported in the literature, and that drainage density varies depending on climate and geology. For areas we are modeling in the dry Southern Great Plains region of the US, a spatially constant value of 
$2.5 \mathrm{~km}^{-1}$ has been assumed. This value is consistent with a hillslope length of $200 \mathrm{~m}$ that is most common for the studied region.

\subsubsection{Channel routing parameters}

Channel parameters $Q_{\mathrm{s}}$ and $m$ of the discharge and channel cross-section relationship (Eq. (6)) must be prescribed for all grid cells of interest. There are two options to define these parameters: (1) use of the Chezy-Manning approximation of a discharge and cross-section relationship assuming a prismatic channel, referred as a channel shape method, and (2) direct estimation of these parameters from an empirical discharge and cross-section relationship, referred as a rating curve method.

The basic idea for both methods is to disaggregate information from outlet measurements representing basin integrated properties into interior grid cell parameters using local geomorphological properties. The US Geological Survey (USGS) flow measurement data, including top width $B$, cross-section $A$, channel depth $H$, and discharge at stream gaging stations are used in this study. Eqs. (10) and (11) are used to define the relationship between the crosssection shape parameters $a$ and $b$ and measured values of $B, A$, and $H$ assuming a prismatic channel:

$B=a H^{b}$

$B=\left[a(b+1)^{b}\right]^{1 /(b+1)} A^{b /(b+1)}$

In channel shape method, parameters $Q_{\mathrm{s}}$ and $m$ are defined from the Chezy-Manning equation assuming a prismatic channel:

$Q=\frac{\sqrt{S_{\mathrm{c}}}}{n_{\mathrm{c}}}\left[a(b+1)^{b}\right]^{-2 / 3(b+1)} A^{(b+5 / 3) /(b+1)}$

It follows from Eq. (12) that

$Q_{\mathrm{s}}=\frac{\sqrt{S_{\mathrm{c}}}}{n_{\mathrm{c}}}\left[a(b+1)^{b}\right]^{-2 / 3(b+1)}$,

$m=\frac{b+5 / 3}{b+1}$

where $S_{\mathrm{c}}$ and $n_{\mathrm{c}}$ are channel slope and roughness, respectively, and $a$ and $b$ are channel shape parameters defined previously.

Four channel property grids must be defined for this option: slope, roughness, and shape parameters, $a$ and $b$. Channel slope at each grid cell is derived from high resolution (e.g. $30 \mathrm{~m}$ ) DEM data. Channel slopes are computed for synthetic stream segments defined by the DEM, and the average slope of the segments forming the largest stream branch within a model cell is assigned to that cell. As should be the case, channel slope estimates are significantly different than the hillslope slope values. Channel roughness values are calculated using an empirical equation derived by Tokar and Johnson (1995) based on analyses of a number of stream channels in the US:

$n_{\mathrm{c}}=n_{\mathrm{o}} S_{\mathrm{c}}^{0.272} F^{-0.00011}$

where $F$ is the upstream drainage area. Locally applicable values for the coefficient $n_{\mathrm{o}}$ can be estimated from the known values of roughness, $n_{\mathrm{c}, \mathrm{o}}$, and slope, $S_{\mathrm{c}, \mathrm{o}}$, at the basin outlet. Outlet roughness is calculated from the Chezy-Manning equation using flow measurements. Because of data errors and the dependency of roughness on flow conditions, a number of $n_{\mathrm{c}, \mathrm{o}}$ values may be observed. In our applications, values at high flow levels are preferred because of the importance of flood modeling.

Channel shape parameter values are first estimated at the basin outlet by fitting a curve to a plot of $A$ vs. $B$ data. Two basic geomorphologic assumptions that follow from channel geometry laws (Strahler, 1957; Horton, 1945) are used to estimate channel shape parameters at upstream cells:

(1) the ratio of channel-forming flows at different cells, $r_{Q, i}$, equals the ratio of drainage areas, $F$, above these cells:

$$
r_{Q, \mathrm{i}}=\frac{Q_{\mathrm{i}}}{Q_{\mathrm{o}}}=\frac{F_{\mathrm{i}}}{F_{\mathrm{o}}}
$$

(2) the ratio of channel cross-sectional areas of different channels, $r_{A, i}$, is a known function of stream orders. In this study, we adopted a function suggested by Gorbunov (1971):

$$
r_{A, \mathrm{i}}=\frac{A_{\mathrm{i}}}{A_{\mathrm{o}}}=\frac{0.013^{0.83^{k_{\mathrm{c}, \mathrm{i}}}-0.83^{k_{\mathrm{c}, \mathrm{o}}}}}{R_{1}^{k_{\mathrm{c}, \mathrm{o}}-k_{\mathrm{c}, \mathrm{i}}}}
$$

In Eqs. (15) and (16), the subscript ' $i$ ' denotes any upstream cell and the subscript 'o' denotes the value 
Table 2

Stream order definition based on channel length or area above

\begin{tabular}{lcc}
\hline Stream order & Channel length $(\mathrm{km})$ & Area above $\left(\mathrm{km}^{2}\right)$ \\
\hline 1 & 0.8 & 0.3 \\
2 & 1.5 & 0.9 \\
3 & 2.8 & 2.7 \\
4 & 5.1 & 7.6 \\
5 & 9.3 & 21.6 \\
6 & 16.9 & 61.3 \\
7 & 31.0 & 176.3 \\
8 & 57.0 & 509.4 \\
9 & 104.0 & 1452.0 \\
10 & 190.0 & 4149.0 \\
11 & 338.0 & $11,317.0$ \\
12 & 620.0 & $32,562.0$ \\
13 & 1140.0 & $82,908.0$ \\
14 & 2090.0 & $235,754.0$ \\
15 & 3810.0 & $663,862.0$ \\
\hline
\end{tabular}

at the outlet, $R_{1}$ is Horton's length ratio, and $k_{\mathrm{c}}$ is the stream order. An advantage of using this stream order relationship rather than relationships that are strictly functions of drainage area is that the $R_{1}$ parameter can be varied to reflect local characteristics. In our analysis, we use $R_{1}=2.1$. To identify the stream order of each model cell, Rzhanitsyn's classification (Rukovodstvo, 1989) defining stream order as a function of stream length (Table 2), and the Willemin (2000) formula defining the relationship between channel length $(L, \mathrm{~km})$ and drainage area $\left(F, \mathrm{~km}^{2}\right)$ were used:

$L=1.6 F^{0.58}$

Distributed $a_{i}$ values can then be back-calculated from Eq. (11) for a selected flow level at the outlet, and estimated values of $r_{A, \mathrm{i}}$ and $r_{Q, \mathrm{i}}$ from Eqs. (15) and (16), respectively,

$a_{\mathrm{i}}=(b+1)^{-b}\left[\frac{\sqrt{S_{\mathrm{c}, \mathrm{i}}}}{n_{\mathrm{c}, \mathrm{i}}} \frac{\left(r_{A, \mathrm{i}} A_{\mathrm{o}}\right)^{m}}{r_{Q, \mathrm{i}} Q_{\mathrm{o}}}\right]^{3(b+1) / 2}$

In our applications, the shape parameter $b$ is assumed to be constant within a basin, equaling an estimated value at the outlet. With known channel geometry at each cell, values of channel specific discharge, $Q_{\mathrm{s}}$, and exponent parameter $m$ are estimated from Eq. (13) and used for kinematic routing calculations.
In the rating curve method, the channel specific discharge $\left(Q_{\mathrm{s}}\right)$ and the exponent $(m)$ in Eq. (6) are estimated at the outlet directly by fitting a curve to the $Q$ vs. $A$ measured data. The same geomorphologic assumptions are used to estimate $Q_{\mathrm{s}}$ and $m$ values at upstream cells. From Eqs. (15) and (16), it can be shown that specific discharge at $i$ th grid cell is a function of specific discharge at the outlet:

$Q_{\mathrm{s}, \mathrm{i}}=Q_{\mathrm{s}, \mathrm{o}} \frac{F_{\mathrm{i}}}{F_{\mathrm{o}}} r_{A, \mathrm{i}}^{m}$

As in the channel shape method, the exponent parameter $m$ is a constant that is equal to an estimated outlet value. An advantage of this method is that it does not require estimation of channel slope and roughness at upstream points. However, because of this, the method may poorly represent channel geometry if there are distinct portions of basin, which have significant differences in average channel slopes (e.g. transition from mountain region to a plain). Note that values of the specific discharge and exponent parameters from these two options may differ because of empirical curve fitting to different experimental data. From Eqs. (11), (16), and (19) it can be shown that

$\left(\frac{Q_{\mathrm{s}, \mathrm{i}}}{Q_{\mathrm{s}, \mathrm{o}}}\right)_{1}=\left(\frac{Q_{\mathrm{s}, \mathrm{i}}}{Q_{\mathrm{s}, \mathrm{o}}}\right)_{2} r_{A, \mathrm{i}}^{m_{2}-m_{1}}$

where subscripts 1 and 2 denote estimates from the first and second methods, respectively. Eq. (20) suggests that specific discharge ratios from the two options are equal if the exponent parameters are equal. Fig. 2 compares discharge and channel cross-section area relationships derived from the channel shape and rating curve methods. As seen from the figure, both methods represent reasonably well measured data with slightly better approximation of low discharges from the rating curve method.

\subsection{Modification/adjustment of model parameters}

Some tests of a priori parameters of the SAC-SMA model in lumped simulations were presented in Koren et al. (2000), Duan et al. (2001), and Koren et al. (2003). While overall statistics of simulation results showed that a priori parameters produced similar simulations to those using carefully calibrated 


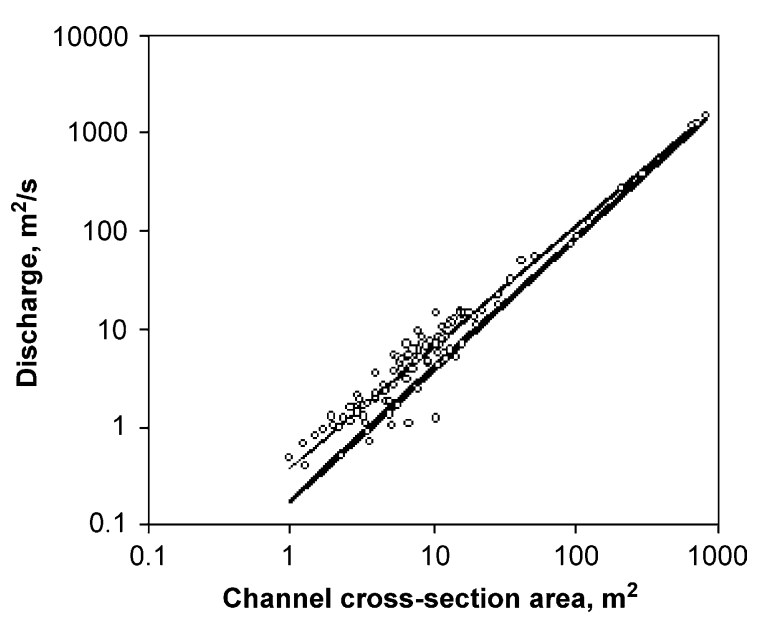

Fig. 2. Discharge and channel cross-section area relationships generated using the channel shape (thick line) and the rating curve (thin line) methods for the Baron Fork at Eldon; measured data are shown in circles.

parameter sets for a number of river basins, it was found that these derived relationships could not account for some specific local river basin conditions. Consequently, the accuracy of a priori parameters can vary for different regions. As an example, the estimated parameters of the lower layer free water storage may not be reliable in regions with deep ground water because soils information is defined only to a depth of $1.5-2.5 \mathrm{~m}$. Other limitations arise because the approach is based on physical assumptions regarding relationships between model parameters and soil properties, and among soil properties themselves. Although most assumptions are obvious, some quantitative expressions were assigned empirically using SAC-SMA calibration results from a limited number of river basins. State Soil Geographic Database (STATSGO) data consist of soil texture data derived from 1:250,000 scale soil maps and re-sampled into $1 \times 1 \mathrm{~km}^{2}$ grids for 11 soil layers. Another limitation on the reliability of a priori parameters is that in the original STATSGO data only representative texture values are available over large areas (100-200 km² in some regions). Some concerns apply to the reliability of a priori hillslope and channel routing parameters as well. Therefore, to obtain operational predictions of the highest possible accuracy, a priori parameters should be adjusted if there are observed rainfall-discharge data. The main objective of deriving a priori parameters is to give not only reasonable initial estimates but an indication of their spatial pattern as well.

The HL-RMS has a flexible mechanism for assigning parameter sets. The basic option is to select from grids of a priori parameters generated over large regions. These parameters can be easily replaced by a constant value or scaled to a desired spatial average value over selected local watersheds. The latter method is used to adjust SAC-SMA water balance model parameters. Koren et al. (2003) used ratios of a priori parameters to scale parameters from a nearby, calibrated basin to estimate parameters for ungaged basins. They concluded that while a priori grids are beneficial in regional analysis to account for a spatial pattern of parameters, scaling is helpful in removal of their local biases. The HL-RMS can use this approach to scale a priori SAC-SMA parameter grid cell values over selected watershed by the ratio of the SAC-SMA parameter from lumped calibration to the average parameter value from a priori grid. Because calibrated SAC-SMA parameters are scale dependent (Koren et al., 1999; Finnerty et al., 1997), some further fine tuning of selected scaled parameters might be required in distributed simulations. Fortunately, the scale effect is reduced significantly if the ratio of calibration to distributed simulation scales decreases. Koren et al. (1999) observed about a 3\% runoff difference when calibrated SAC-SMA parameters derived for a $1000 \mathrm{~km}^{2}$ basin were applied at a grid scale of $16 \mathrm{~km}^{2}$.

A scaling procedure is also used to adjust kinematic routing parameters. Because there is no lumped equivalent to compare, adjustment is performed by a trial-and-error process comparing flood event shape and timing.

\section{Results and discussion}

Even though HL-RMS is still under development and much work remains in the areas of parameterization and calibration, it is appropriate to present results from testing the model components and as a whole. In this section, we present preliminary results that provide information on the practicality and flexibility of HL-RMS. There were no significant calibration 


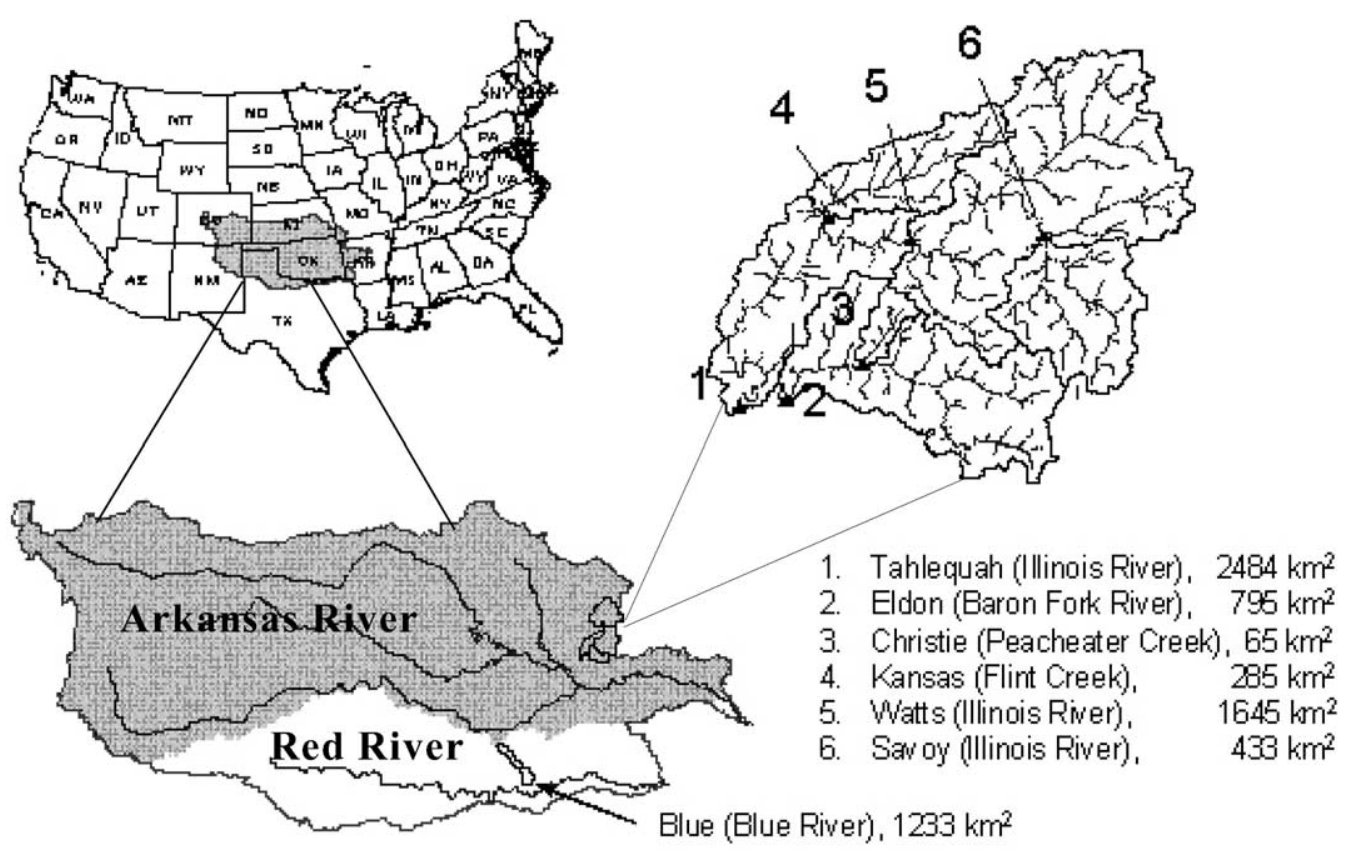

Fig. 3. Test region in the Arkansas-Red River basins, and DMIP watershed locations.

efforts in these distributed simulations. The tests described here were performed on watersheds within the Arkansas-Red River Basins in Oklahoma shown in Fig. 3. The main reason for this is that this region has the longest archive of 4-km NEXRAD-based multi-sensor precipitation grids, and these rainfall estimates have been evaluated more thoroughly (Johnson et al., 1999; Young et al., 2000) than those produced in other parts of the country. In addition, these basins had few complications such as snow, reservoirs, and complex topography such as mountainous areas. All basins shown in Fig. 3 are being studied as part of the Distributed Modeling Intercomparison Project (DMIP) (DMIP, 2002) initiated by NWS. It is expected that comprehensive analysis of DMIP results will be published this year in the special issue of the Journal of Hydrology. Here, we will discuss specific results for only a few of these basins.

\subsection{HL-RMS application over a large region}

Two main goals of this application are to understand the overall performance of HL-RMS without any parameter calibration and to test the computational efficiency of the distributed system applied over a large region. The entire Arkansas River basin in Oklahoma (Fig. 3) is used in this study. With a total drainage area of $409,300 \mathrm{~km}^{2}$, the basin encompasses a wide variety of climatic conditions, ranging from an arid/semi-arid region in the western part to a humid region in the eastern part. Annual precipitation varies from $300 \mathrm{~mm}$ in the northwest portion of the region to $1500 \mathrm{~mm}$ in the southeastern portion. Potential evaporation varies much less throughout the region. Consequently, significant differences in annual runoff for the northwest $(2 \mathrm{~mm})$ and southeastern $(700 \mathrm{~mm})$ portions of the basin are present. The steep gradient of climatological annual runoff coefficient from the west to the east can be seen in Fig. 4.

The $4 \mathrm{~km}$ grid cells used in NWS algorithms to map multi-sensor precipitation are selected as the basic modeling unit. The 4-km resolution is adequate to resolve important spatial variability in rainfall that can occur across basins modeled by NWS operational offices, while still maintaining acceptable computational performance. Certainly, there is a lower limit 


\section{(b) Annual Runoff Ratio}

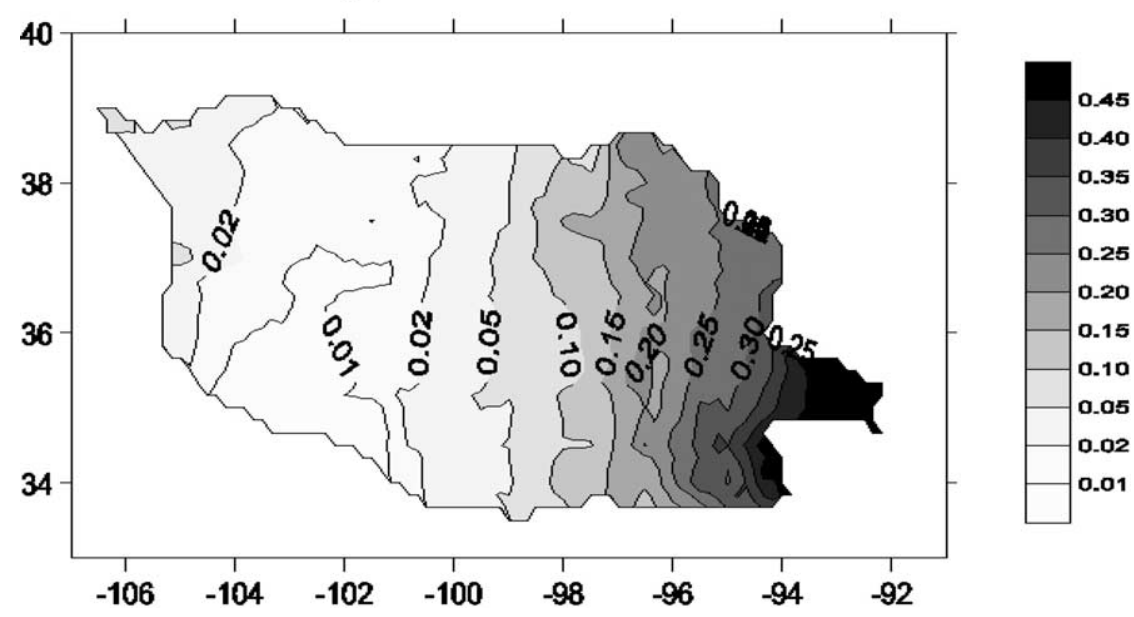

Fig. 4. Climatological annual runoff coefficient (Annual Runoff Ratio) distribution over Arkansas-Red River basins. X-axis is the West Longitude, and Y-axis is the North Latitude.

on the basin size that can be modeled with this resolution. Some effect of grid resolution will be discussed in Section 4.2.

SAC-SMA parameter grids at the $4 \mathrm{~km}$ scale were generated as simple averages from $1-\mathrm{km}$ a priori parameter grids available over the conterminous US (Section 3.1). These grids display a large variability of basin properties that affect runoff generation processes over this region. As one would expect, a deeper soil layer has heavier soils. Therefore, a uniform soil profile assumption may be not valid for rainfall-runoff modeling. The derivation of a priori SAC-SMA grids used in this study accounted for heterogeneous profile properties. There is no clear pattern in parameter variation from the west to the east as there is with observed annual runoff (Fig. 4). Rather, the SACSMA parameters display some similarity with a stream channel structure.

Routing parameter grids are derived using measured discharge data from only a few stations on the main stem of the Arkansas river. The simpler rating curve method from Section 3.2.2 is used to estimate discharge and channel cross-section relationship parameters $\left(Q_{\mathrm{s}}\right.$ and $\left.m\right)$ at seven gage locations. Table 3 lists these gages and estimated parameters at these points. Note, that the most downstream gage parameters may be not representative because of reservoir effects. A parameter estimation procedure at upstream grid cells is applied sequentially from downstream to upstream gages independently. At each estimation loop, grid cell parameters above a selected gage, estimated previously from the next downstream gage, are overwritten by new estimates from the selected upstream gage. Fig. 5 is a plot of three consecutive specific discharge $\left(Q_{\mathrm{s}}\right)$ grids generated using only the most downstream gage, the two most downstream gages, and all seven gages. As seen from Fig. 5, the overall spatial pattern of specific discharge grids reasonably reproduces the stream channel structure. The most significant changes occur at the most upstream gages. Fig. 5 also suggests that the routing parameter estimation procedure is robust. Plots $a$ and $b$ in this figure display much similarity although they were generated using two outlets that represent as much as two time different upstream areas.

A continuous HL-RMS run for a two-year period was performed using all a priori parameter grids. For an NWS operational application, this type of run is feasible. A one month simulation in a quasi-forecast mode for the entire Arkansas River basin required just 10-15 min of CPU time on an HP9000/J5000 workstation. We do not initially expect accurate hydrograph simulations in many parts of the basin because a priori estimates may not account for some local conditions, and because there are numerous processes 
Table 3

Estimated parameters of discharge and channel cross-section relationships at selected gages on the main stem of the Arkansas river (from downstream to upstream)

\begin{tabular}{|c|c|c|c|c|c|}
\hline Outlet name & Latitude & Longitude & Drainage area $\left(\mathrm{km}^{2}\right)$ & Specific discharge, $Q_{\mathrm{s}}\left(\mathrm{m}^{3} / \mathrm{s} / \mathrm{m}^{2 \mathrm{~m}}\right)$ & Power parameter $(\mathrm{m})$ \\
\hline Ft. Smith & 35.39 & -94.43 & 388,440 & 0.0008 & 2.000 \\
\hline Tulsa & 36.14 & -96.01 & 193,253 & 0.0133 & 1.670 \\
\hline Arkansas City & 37.06 & -97.06 & 113,217 & 0.1620 & 1.315 \\
\hline Dodge City & 37.74 & -100.03 & 79,254 & 0.3800 & 1.155 \\
\hline John Martin & 38.07 & -102.93 & 48,990 & 0.1100 & 1.439 \\
\hline Los Animos & 38.08 & -103.22 & 36,198 & 0.3140 & 1.210 \\
\hline Pueblo & 38.25 & -104.61 & 12,375 & 0.2610 & 1.265 \\
\hline
\end{tabular}
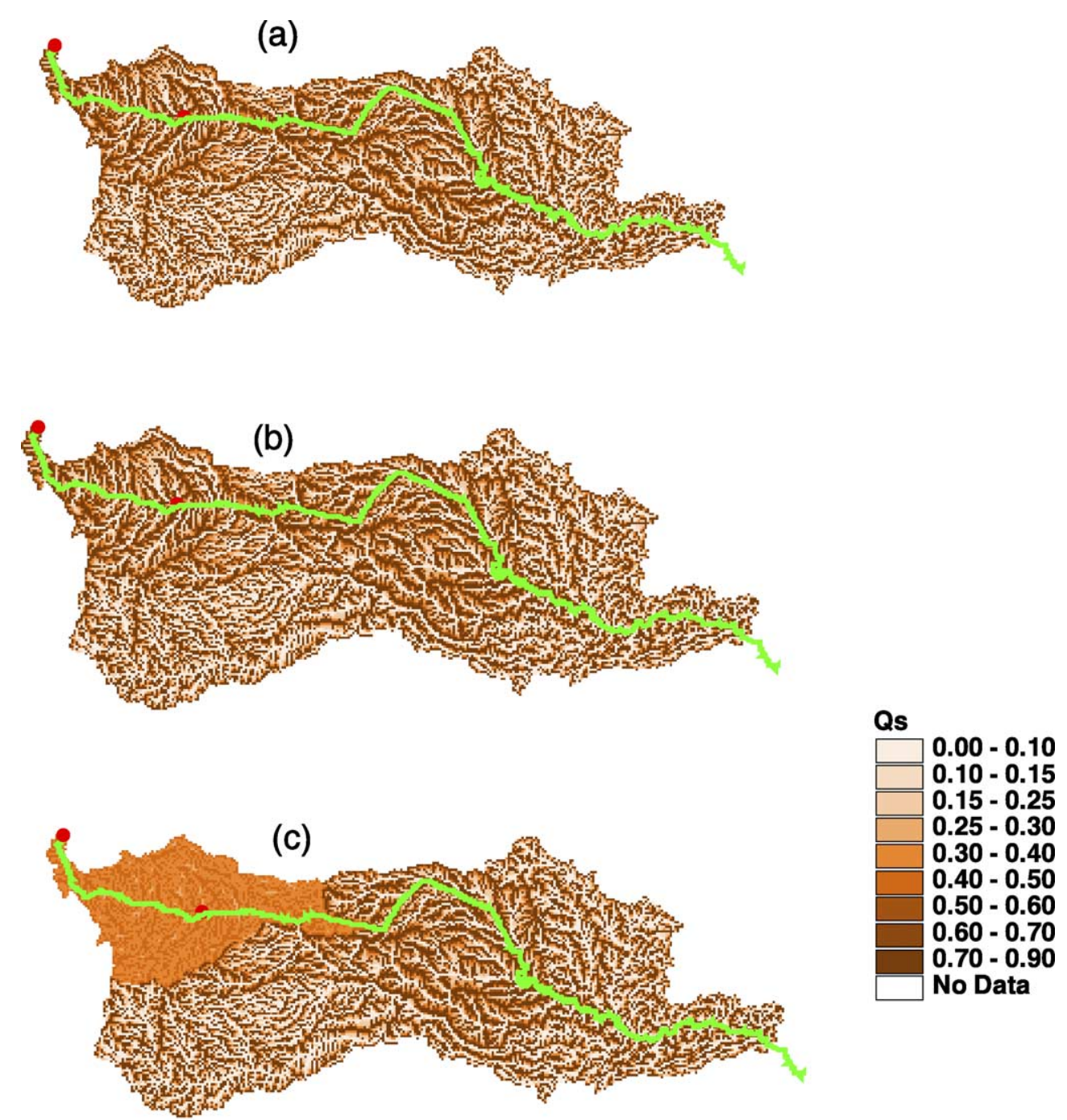

Fig. 5. Specific discharge grids over the Arkansas River basin estimated using (a) the most downstream gage, (b) two the most downstream gages, and (c) all 7 gages. 


\section{Sum of Rainfall Feb. 21-22}
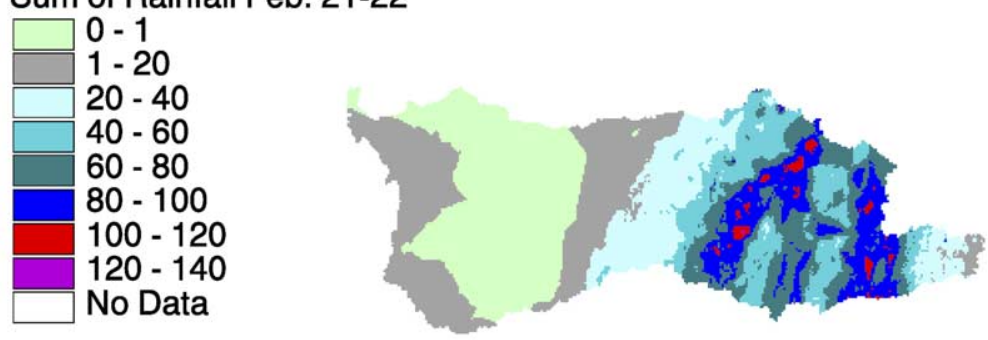

2/20/1997 0:00

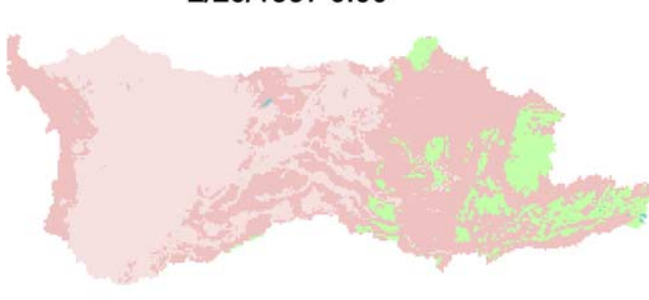

2/20/1997 0:00

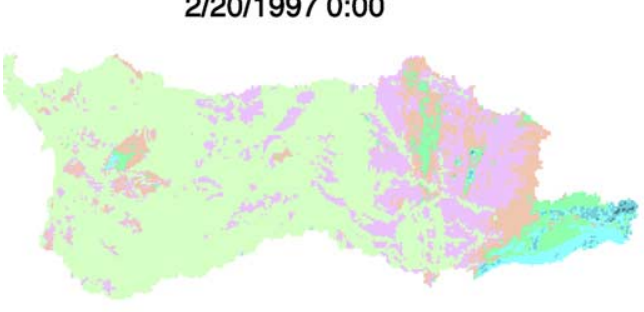

2/20/1997 0:00

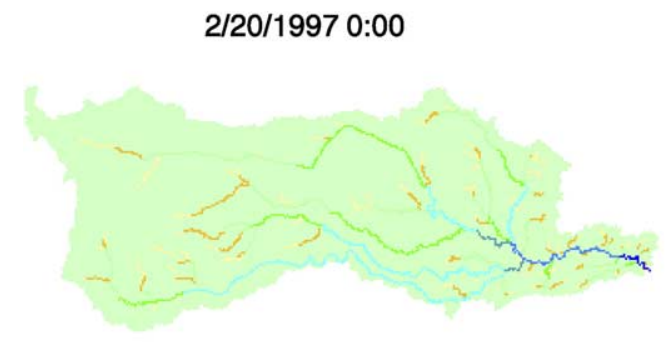

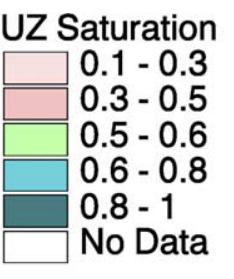

2/21/1997 6:00

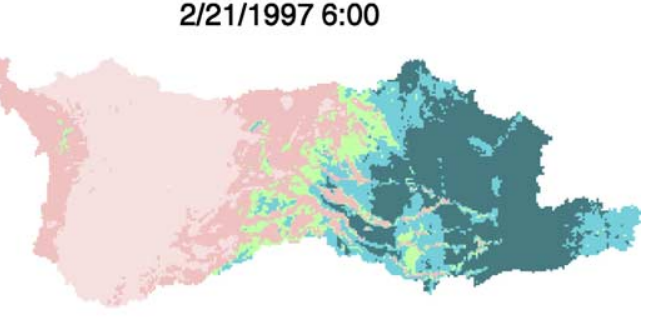

2/21/1997 6:00

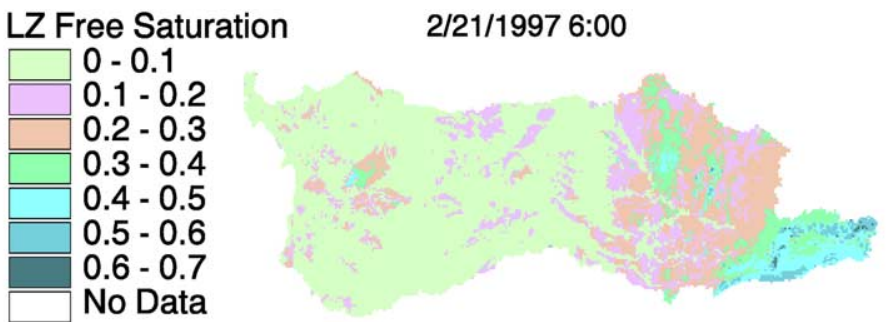

2/23/1997 6:00
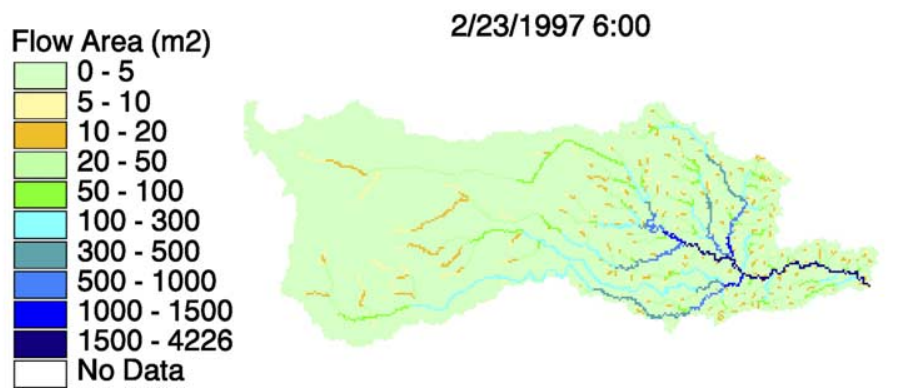

Fig. 6. Simulated SAC-SMA states (UZ Saturation and LZ Free Saturation) and channel cross-section area (Flow Area) over the Arkansas River basin before and after a storm. Storm event cumulative rainfall is also shown in the top plot.

that are not yet represented in HL-RMS (e.g. reservoirs, backwater effects, and the weakness of the kinematic routing to represent wave propagation on large flat rivers). However, the model can provide high resolution information on drought and flood conditions over a large region which can be used, at least qualitatively, for flash-flood monitoring without further development. As an example, Fig. 6 shows soil moisture and channel state grids over the Arkansas River basin before and after a storm event which can 
identify potential dry and flood prone areas to a $4 \mathrm{~km}$ grid resolution. In this figure, soil moisture states were converted into soil moisture saturation ratios (UZ for the upper zone total tension and free water, and LZ for the lower zone free water). As expected, the upper zone is more sensitive to a short-term rainfall pattern than the lower zone. At the same time, differences in local basin properties transform significantly the rainfall-based spatial pattern. At this time, we do not have representative measured soil moisture data to compare. However, future progress in analyses of satellite-based soil moisture estimates may provide valuable data bases to evaluate model results. Channel cross-section area maps provide spatial and temporal distribution of available fresh water in a stream network.

HL-RMS runs over large areas provide a framework for transitioning from a low resolution basin representation (lumped type approach) to a high resolution prediction system. Studies on specific watersheds can begin to populate the HL-RMS initial grids with more accurate parameter estimates, and to refine the regional picture. Base regional runs also help to identify the most critical watersheds to work with, and to analyze effects of parameter estimate improvements over wide range of basins. As an example, Fig. 7 shows the sensitivity of simulated

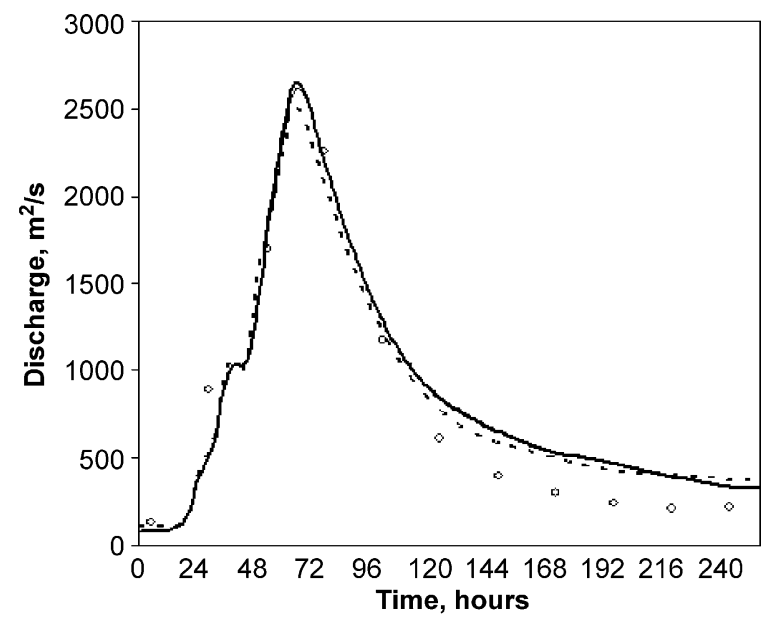

Fig. 7. Simulated hydrographs at the Arkansas City gage using routing parameter estimates from: Arkansas City (thick line), Tulsa (thin line), and Ft. Smith (dotted line). Observed daily discharges are shown in circles, October 31-November 11, 1998. outlet hydrograph to refinement of routing parameters by using the gage closest to the outlet. It suggests that for the selected outlet, Arkansas City, the effect of routing parameter extrapolation from a basin as large as $388,440 \mathrm{~km}^{2}$ (Ft. Smith) may not be significantly different than extrapolation from a $113,217 \mathrm{~km}^{2}$ basin (Tulsa) although estimated discharge vs. cross-section relationships differ significantly. Note that observed hydrograph was available at a daily time interval while simulation results were plotted at hourly time interval.

\subsection{Hydrograph simulations at selected watershed outlets}

These tests were performed for a number of headwater watersheds within the domain of the Arkansas-Red Rivers as shown in Fig. 3. These basins range in drainage areas from a few tens to a few thousand square kilometers. Grids of a priori SACSMA parameters discussed in Section 4.2 were used as initial estimates. However, channel specific discharge and power parameter grids were replaced by new estimates using discharge measurements at the selected watershed outlets. Both methods described in Section 3.2.2, are used to generate these grids. Because these parameter extrapolation procedures are based on general stream channel law assumptions, it is not easy to evaluate them quantitatively using local point measurements. Fig. 8 is a qualitative check of the pattern of channel width variations along the main stem of the Blue River predicted using channel

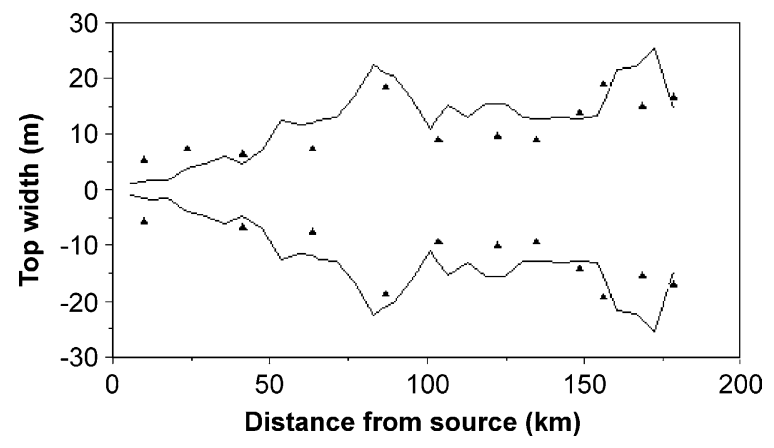

Fig. 8. Channel top width of the Blue River derived using the channel shape method at a selected flow level. Measured bankfull width is shown with triangles. 
shape method compared to the pattern of actual channel top width measurements made in the field. Our main concern is the pattern rather than the absolute width because channel bankfull width is measured in the field and there is no channel bank in the simplified conceptual channel defined by Eq. (10). The estimated widths in Fig. 8 agree well with measured bankfull widths over the entire Blue river stream channel profile. As one would expect, the top width generally increases with increasing channel order while significant deviations occur because of changes in channel slope and roughness. The simpler rating curve option does not provide information on channel geometry, and as a result, cannot be useful in monitoring inundated areas during flood events. All hydrograph results presented in this section are based on routing parameter grids generated using the channel shape method.

Two critical questions to consider in evaluating the potential benefits of distributed modeling for NWS operations are (1) whether a distributed model can produce simulations that are comparable to or better than simulations from existing lumped models, and (2) is it possible to define a distributed parameter model calibration strategy that is robust across spatial scales. We consider the ability to produce simulations that are comparable to lumped simulations a positive result because there are other potential benefits from running a distributed model: the ability to simulate flows at small, ungaged outlets within a watershed, and the ability to incorporate future sources of spatial data that describe hydrologic variables are good examples.

Continuous discharge simulations at an hourly time step were generated from June 1993 to July 2000 for the DMIP watersheds in Fig. 3. HL-RMS results are evaluated against both hourly observed hydrographs and simulated hydrographs from a lumped version of the SAC-SMA model paired with a unit hydrograph (UHG) routing procedure. First, 'reference' results were generated using a priori estimates of water balance and routing parameters for both HLRMS and a lumped application of the SAC-SMA/ UHG model. A priori lumped SAC-SMA parameters were calculated as a simple average of $1-\mathrm{km}$ grids, and unit hydrographs were estimated using an extended Clark's method (Kull and Feldman, 1998). Second, a priori SAC-SMA parameter grids were adjusted as discussed in Section 3.3, using lumped calibration results for defined watersheds. Lumped calibration was performed independently using NWS interactive manual calibration procedures (Smith et al., 2003). Major adjustments to gridded parameter values were achieved by direct scaling from lumped calibrated parameters. Further minor adjustments of a few upper zone parameter scale factors were made using a manual trail-and-error process.

Table 4 presents statistical analyses of these distributed and lumped simulations. Shown are two statistics for selected flood events: percent of mean absolute error of flood runoff, $\delta_{\mathrm{vol}}$, and percent of mean absolute error of flood peak, $\delta_{\text {peak }}$. Also presented are two overall statistics describing the entire simulation period: percent of root mean square error, $\delta_{\mathrm{RMS}}$, and a correlation coefficient of hourly discharges, $R$ :

$$
\begin{aligned}
\delta_{\mathrm{vol}}= & \frac{\sum_{i=1}^{N}\left|V_{\mathrm{o}, i}-V_{\mathrm{s}, i}\right|}{\sum_{i=1}^{N} V_{\mathrm{o}, i}} \times 100 \% \\
\delta_{\mathrm{peak}} & =\frac{\sum_{i=1}^{N}\left|Q_{\mathrm{po}, i}-Q_{\mathrm{ps}, i}\right|}{\sum_{i=1}^{N} Q_{\mathrm{po}, i}} \times 100 \% \\
\delta_{\mathrm{RMS}} & =\frac{\sqrt{\sum_{j=1}^{M}\left(Q_{o, j}-Q_{s, j}\right)^{2} / M}}{\sum_{j=1}^{M} Q_{o, j} / M} \times 100 \%
\end{aligned}
$$

where $V_{\mathrm{o}, i}$ and $V_{\mathrm{s}, i}$ are observed and simulated flood event runoffs, $Q_{\mathrm{po}, i}$ and $Q_{\mathrm{ps}, i}$ are observed and simulated flood peaks, $N$ is a number of selected flood events, $Q_{\mathrm{o}, j}$ and $Q_{\mathrm{s}, j}$ are observed and simulated hourly discharges, and $M$ is the number of hourly discharges for the simulation period.

A few observations can be made about the results in Table 4. While distributed and lumped simulations can both produce reasonable flood event simulations for calibrated watersheds, distributed model results are slightly better. However, only Blue River simulations showed improvements over lumped simulations for the entire test period. Other watersheds yielded overall results comparable to lumped simulations with a slight decrease in accuracy. It is important to note that simulations for two nested basins, Savoy and Kansas, (not calibrated directly, but 
Table 4

Accuracy statistics for selected headwater watersheds in the Arkansas river basin

\begin{tabular}{|c|c|c|c|c|c|c|c|c|c|}
\hline \multirow[t]{2}{*}{ Watershed } & \multirow[t]{2}{*}{ Area $\left(\mathrm{km}^{2}\right)$} & \multicolumn{4}{|c|}{ HL-RMS simulations } & \multicolumn{4}{|c|}{ Lumped simulations } \\
\hline & & $\delta_{\mathrm{vol}}$ & $\delta_{\text {peak. }}$ & $\delta_{\mathrm{RMS}}$ & $R$ & $\delta_{\mathrm{vol}}$ & $\delta_{\text {peak. }}$ & $\delta_{\mathrm{RMS}}$ & $R$ \\
\hline \multicolumn{10}{|c|}{ Calibrated parameters } \\
\hline Blue & 1232.8 & 25.0 & 25.0 & 139.0 & 0.87 & 23.0 & 35.0 & 141.0 & 0.86 \\
\hline Eldon & 795.1 & 16.4 & 25.7 & 131.0 & 0.90 & 18.5 & 26.0 & 114.5 & 0.92 \\
\hline Tahlequah & 2483.8 & 11.3 & 20.5 & 70.8 & 0.92 & 12.6 & 25.8 & 64.9 & 0.94 \\
\hline Watts & 1644.6 & 11.9 & 26.4 & 86.5 & 0.92 & 12.9 & 30.2 & 82.8 & 0.93 \\
\hline Savoy $^{\mathrm{a}}$ & 432.8 & 19.9 & 52.2 & 185.6 & 0.86 & 20.9 & 52.0 & 196.7 & 0.85 \\
\hline Kansas $^{\mathrm{a}}$ & 284.9 & 23.8 & 53.0 & 161.7 & 0.81 & 23.7 & 55.8 & 189.6 & 0.73 \\
\hline Christie $^{\mathrm{a}}$ & 64.8 & 55.4 & 115.0 & 360.8 & 0.72 & 52.8 & 126.0 & 338.9 & 0.83 \\
\hline \multicolumn{10}{|c|}{ Uncalibrated parameters } \\
\hline Blue & 1232.8 & 38.0 & 40.3 & 187.0 & 0.81 & 31.0 & 42.8 & 163.0 & 0.83 \\
\hline Eldon & 795.1 & 27.4 & 45.3 & 160.0 & 0.84 & 30.2 & 53.4 & 181.9 & 0.79 \\
\hline Tahlequah & 2483.8 & 13.4 & 19.2 & 84.5 & 0.90 & 23.7 & 25.6 & 97.2 & 0.86 \\
\hline Watts & 1644.6 & 13.8 & 26.0 & 105.8 & 0.89 & 23.1 & 30.5 & 109.9 & 0.87 \\
\hline Savoy & 432.8 & 22.4 & 49.8 & 194.2 & 0.85 & 29.1 & 54.5 & 228.6 & 0.79 \\
\hline Kansas & 284.9 & 24.2 & 52.2 & 185.1 & 0.75 & 26.9 & 57.1 & 221.1 & 0.62 \\
\hline Christie & 64.8 & 34.8 & 88.3 & 323.5 & 0.70 & 32.4 & 67.1 & 254.7 & 0.78 \\
\hline
\end{tabular}

Values in italic mean that this statistics is better for Distributed (Lumped) simulations compared to Lumped (Distributed).

a Nested basins (Savoy and Kansas are sub-basins of Tahlequah, Illinois river, and Christie is sub-basin of Eldon, Baron Fork river): these subbasins actually were not calibrated, instead parent basin calibrated parameters were used in simulations.

parameters from the calibration of the parent basin were applied instead) outperformed lumped simulations even more consistently than we would expect from a distributed model. Consistent improvements from the uncalibrated parameter version of HL-RMS over uncalibrated lumped simulations were achieved for most watersheds except the Blue River. It means that the spatial pattern of a priori parameters coincides hydrologically with the patterns of spatially variable rainfall. In other words, the spatial variation in the hydrologic model parameters combines with the patterns of precipitation to produce reasonable discharge hydrographs. This fact is critical in developing a distributed model calibration strategy. It suggests that the parameter scaling procedure used in this analysis may be a reasonable component in a multi-step calibration process. Poor results were achieved for both distributed and lumped simulations for the smallest watershed (Peacheater Creek at Christie). Note that there was no calibration at this outlet. It is perhaps not difficult to accept this result because the effects of the scaling factor decrease significantly if calibrated parameters from a large parent basin (in this case Baron Fork at Eldon) are applied at much smaller nested basin (Koren et al., 1999). Another reason is that only four grid cells are used in a distributed representation of this basin. Such a small number of cells may not be enough to adequately capture the rainfall variability and properly represent the actual channel structure (Kouwen and Garland, 1989).

While Table 4 presents overall statistics, Fig. 9a and $b$ are plots of peak and volume errors of each selected flood event calculated from distributed and lumped simulations for the Baron Fork river at Eldon. As seen from these figures, HL-RMS outperforms lumped simulations for most flood events especially with regard to peak flows. The bigger improvement of flood peak simulations compared to flood volume may be attributed to the combined effects of spatial and temporal variability of rainfall as well as distributed routing. Results of this type were also obtained for other watersheds. Fig. 10 shows hydrographs for two events in the Blue River which were selected from the 7 year continuous hourly simulations. Several other flood events during this period show similar results. 

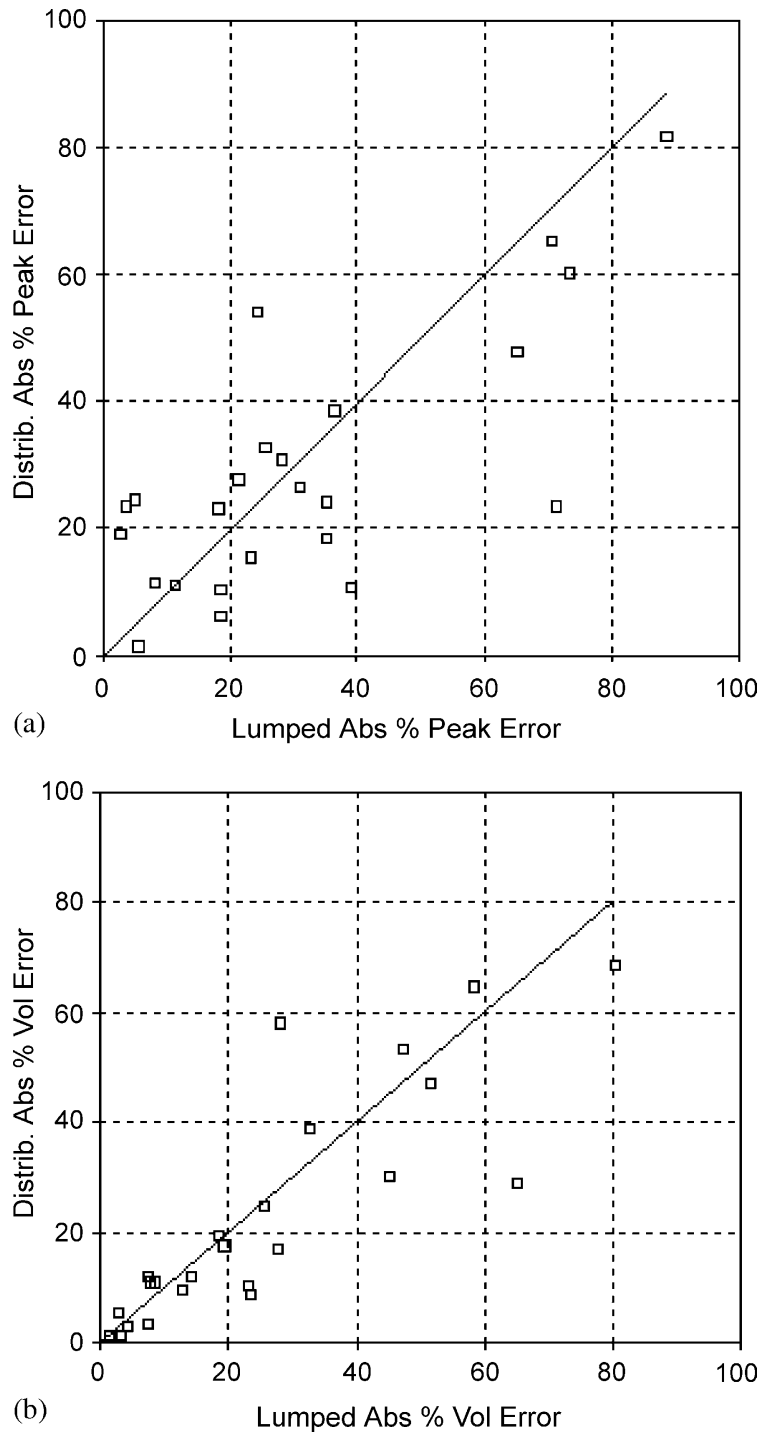

Fig. 9. (a) Peak errors from lumped and distributed simulations for the Baron Fork at Eldon. (b) Flood volume errors from lumped and distributed simulations for the Baron Fork at Eldon.

Fig. 10a shows flood event hydrographs when the rainfall distribution over the watershed was highly non-uniform: $50-120 \mathrm{~mm}$ of rain over less than $35 \%$ of the lower portion of the watershed with only $0-25 \mathrm{~mm}$ rain over the rest of area. Not surprisingly, the distributed model outperforms the lumped model during this flood event. Fig. 10b shows that the lumped and distributed simulations are comparable in cases with less spatial rainfall variability. In this
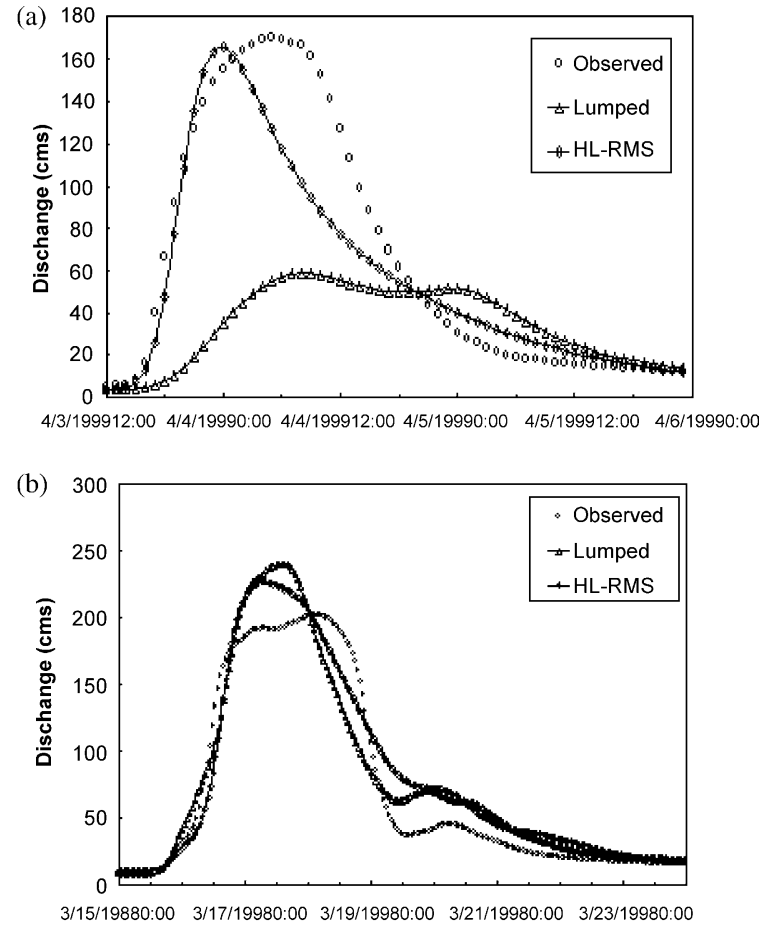

Fig. 10. Observed and simulated hydrographs for the Blue River: (a) non-uniform rainfall, April 3-6, 1999, and (b) uniform rainfall, March 16-23, 1998.

event, rainfall variability was in range of $60-90 \mathrm{~mm}$ over the entire watershed. Although the effects of rainfall variability are evident in other watersheds, they are not as strong as in the Blue River case. The Blue River appears to be unique among the watersheds studied in its response to spatial rainfall patterns, most likely due to a number of factors including differences in basin shape and orientation. The Blue basin is long, narrow, and orthogonal to typical storm directions, which lead to well organized rainfall patterns partially covering either the upper or lower portions of the basin. As a result, flood wave attenuation may vary significantly even for the same amount of total basin lateral inflow. More detailed analysis on this effect and numerical test results can be found in Zhang et al. (2004). One must also consider the possible dampening effects of deeper soils in the Watts and Eldon watersheds. Perhaps the lack of significant gain from a distributed model in Watts 
and Eldon may be explained by the suggestion of Obled et al. (1994) and Naden (1992) that the spatial variability of precipitation may not be sufficiently organized to overcome the effects of hillslope storage and dampening within the basin.

\section{Summary}

Operational river forecasting over a large range of spatial and temporal scales such as that performed by the NWS introduces tremendous demands on hydrologic modeling. Huge data uncertainties and tremendous horizontal and vertical heterogeneities of basin properties may override the benefits of sophisticated physically-based models at some scales. The parameter estimation problem becomes very critical especially when available data in practical applications are reduced to a limited number of local area responses that represent the integrated effects of distributed physical properties. In this regard, lumped conceptual models have an advantage because their parameters represent integrated effects of basin properties, and as a result, they are more readily identified from hydrograph analyses. However, a significant disadvantage with lumped models is the inability to represent the spatial variability of processes such as precipitation and runoff generation.

This study investigates an approach to combine physically-based and conceptual model features in the both stages of distributed modeling: model structure development and estimation of spatially variable parameters. The approach adds more practicality to the process of model parameterization, and facilitates an easier transition from current lumped model-based operational systems to more powerful distributed systems. HL-RMS provides a flexible framework for rainfall-runoff analysis and practical applications of distributed models. Quasi-operational tests suggest also that the system is computationally feasible to run over large regions.

HL-RMS shows the potential to improve the accuracy and resolution of river runoff forecasts. Initial test results suggest that the distributed system produces simulations that are comparable to or better than the simulations generated by a well calibrated lumped model. While improved overall flood event statistics were found for most tested watersheds, the greatest benefit was achieved for events where the spatial variability of rainfall was significant. It is also significant that HL-RMS outperforms a lumped model for uncalibrated nested basins (excluding one basin which is too small to be well represented at the chosen grid scale) that could be the most important benefit of the distributed system.

Schemes developed to estimate distributed routing parameters based on local grid cell and basin outlet integrated properties produce reasonable results for the range of spatial scales studied without any calibration. Progress has been made in quantitatively estimating spatially variable rainfall-runoff parameters by combining soil properties and lumped calibration results, but more robust methods to calibrate the distributed parameter model remain to be defined.

HL-RMS can also provide valuable high resolution information on soil moisture and channel states over large regions that can support better monitoring of drought and flash-flood prone areas, and describe the dynamics of spatially distributed water resources.

\section{Future work}

Although tests performed in this study with actual observed data have shown the potential of distributed modeling, replacing the current lumped model-based NWS operational forecast system with a distributed modeling system is not a trivial task from either a scientific or systems engineering standpoint. Continued improvement of the model parameterization process is needed and well-defined procedures for calibration, real-time data processing, and real-time updating are still lacking, yet they are as important as the use of advanced modeling techniques. Several additional steps are necessary to refine the modeling approach and hasten operational implementation.

1. Refine the rainfall-runoff model parameter estimation procedure to make it less scale dependent and more objective. Success in this area will hasten HL-RMS implementation over a range of basin scales including flash flood type watersheds. 
2. Operational forecasts include a significant number of human quality control steps and run-time modifications for manual state updating. It is more difficult to perform these tasks with a distributed system that generates spatially variable states. Continued research on automatic assimilation/updating techniques (Seo et al., 2003) is needed to develop an objective, robust procedure for real-time modifications of spatially variable boundary conditions and states.

3. Analyze the effects of real-time data uncertainties on simulation results from models of different complexity. The Distributed Modeling Intercomparison Project (DMIP, 2002) that brought a wide range of distributed models provides a good framework for such tests.

4. Run HL-RMS with a priori SAC-SMA parameters in real-time over large areas (e.g. over a River Forecast Center (RFC) domain or multiple RFC region). High resolution soil moisture and channel states may be of immediate use by operational field offices as supplemental diagnostic information, and by researchers for a variety of scale analyses. Continuous real-time runs at an RFC will initiate a learning process for operational users on the strengths and weaknesses of the system, and will identify watersheds where work on parameter fine-tuning will be beneficial.

5. Implement the distributed routing component into the current NWS River Forecast System to route runoff from existing lumped models, thus capturing the spatial variability of the rainfall but not requiring re-calibration of the water balance component. This will require widespread analysis of flow measurement data at many gages over large areas to refine routing parameter estimation methods, to provide better guidance for users in deriving local parameters, and to develop basic routing parameter grids for large areas.

\section{References}

Abbott, M., Bathrust, J., Cunge, J., O’Connell, P., Rasmussen, J., 1986. An introduction to the European Hydrological SystemSysteme Hydrologique European (SHE), 1, History and philosophy of a physically-based, distributed modeling system. Journal of Hydrology 87, 45-59.
Bell, V.A., Moore, R.J., 1998. A grid-based distributed flood forecasting model for use with weather radar data. Part 2. Case studies. Hydrology and Earth System Sciences 2 (3), 283-298.

Beven, K., 1989. Changing ideas in hydrology: the case of physically-based models. Journal of Hydrology 105, 157-172.

Beven, K., 1995. Linking parameters across scales: subgrid parameterizations and scale dependent hydrological models. In: Kalma, J.D., Sivapalan, M. (Eds.), Scale Issues in Hydrological Modeling, Wiley, New York, pp. 263-282.

Boyle, D.P., Gupta, H.V., Sorooshian, S., 2000. Toward improved calibration of hydrologic models: combining the strengths of manual and automatic methods. Water Resources Research 36 (12), 3663-3674.

Boyle, D.P., Gupta, H.V., Sorooshian, S., Koren, V., Zhang, Z., Smith, M., 2001. Toward improved streamflow forecasts: value of semidistributed modeling. Water Resources Research 37 (11), 2749-2759.

Burnash, R.J.C., 1995. The NWS river forecast system-catchment modeling. In: Singh, V.P., (Ed.), Computer Models of Watershed Hydrology, Water Resources Publications, Littleton, CO, pp. 311-366.

Carpenter, T.M., Georgakakos, K.P., Sperfslage, J.A., 2001. On the parametric and NEXRAD-radar sensitivities of a distributed hydrologic model suitable for operational use. Journal of Hydrology 253, 169-193.

Chow, V.T., Maidment, D.R., Mays, L.W., 1988. Applied Hydrology, McGraw-Hill, New York.

Dingman, S.L., 1993. Physical Hydrology, Prentice Hall, Englewood Cliffs, NJ.

DMIP_Distributed Model Intercomparison Project, 2002, http:// www.nws.noaa.gov/oh/hrl/dmip/index.html

Duan, Q., Schaake, J., Koren, V., 2001. A priori estimation of land surface model parameters. In: Lakshmi, V., Albertson, J., Schaake, J. (Eds.), Land Surface Hydrology, Meteorology, and Climate: Observation and Modeling, Water Science and Application, vol. 3. AGU, Washington, DC, pp. 77-94.

Finnerty, B.D., Smith, M.B., D, J., Seo, D.-J., Koren, V.I., Moglen, G., 1997. Sensitivity of the Sacramento soil moisture accounting mode to space-time scale precipitation inputs from NEXRAD. Journal of Hydrology 203 (1-4), 21-38.

Fread, D.L., 1993. Flow routing. In: Maidment, D.R., (Ed.), Handbook of Hydrology, McGraw-Hill, New York, pp. $10.1-10.36$.

Garrote, L., Bras, R.L., 1995. A distributed model for real-time flood forecasting using digital elevation models. Journal of Hydrology 167, 279-306.

Georgakakos, K.P., 2002. Hydrometeorological models for real time rainfall and flow forecasting. In: Singh, V.P., Frevert, D.K. (Eds.), Mathematical Models of Small Watershed Hydrology and Applications, Water Resources Publications, LLC, pp. $593-655$.

Goodrich, D.C., Woolhiser, D.A., Keefer, T.O., 1991. Kinematic routing using finite elements on a triangular irregular network. Water Resources Research 27 (6), 995-1003.

Gorbunov, Yu.V., 1971. Raschet zapasov vody v rechnoy seti na osnove morfologicheskich zakonov (Calculation of a stream 
network water storage based on morphological laws). Meteorologiya i Hydrologiya 2, 57-67.in Russian.

Grayson, R.B., Moore, I.D., McMahon, T.A., 1992. Physically based hydrologic modeling 1. A terrain-based model for investigative purposes. Water Resources Research 28 (10), 2639-2658.

Hogue, T.S., Sorooshian, S., Gupta, H., Holz, A., Braatz, D., 2000. A multistep automatic calibration scheme for river forecasting models. Journal of Hydrometeorology 1, 524-542.

Horton, R.E., 1945. Erosional development of streams and their drainage basins; hydrological approach to quantitative morphology. Bulletin of the Geological Society of America 56, $275-370$.

Johnson, D., Smith, M., Koren, V., Finnerty, B., 1999. Comparing mean areal precipitation estimates from NEXRAD and rain gauge networks. Journal of Hydrologic Engineering 4 (2), 117-124.

Julien, P.Y., Saghafian, B., Ogden, F.L., 1995. Raster-based hydrologic modeling of spatially-varied surface runoff. Water Resources Bulletin 31 (3), 523-536.

Koren, V., Barrett, C.B., 1995. Satellite based, Distributed monitoring, forecast, and simulation (MFS) system for the Nile River. In: Kite, G.W., Pietroniro, A., Pultz, T.J. (Eds.), Application of Remote Sensing in Hydrology, NHRI, Saskatoon, Canada, pp. 187-200.

Koren, V.I., Finnerty, B.D., Schaake, J.C., Smith, M.B., Seo, D.-J., Duan, Q.-Y., 1999. Scale dependencies of hydrologic models to spatial variability of precipitation. Journal of Hydrology 217, 285-302.

Koren, V.I., Smith, M., Wang, D., Zhang, Z., 2000. Use of soil property data in the derivation of conceptual rainfall-runoff model parameters, Proceedings of the 15th Conference on Hydrology, AMS, Long Beach, CA, pp. 103-106.

Koren, V., Smith, M., Duan, Q., 2003. Use of a priori parameter estimates in the derivation of spatially consistent parameter sets of rainfall-runoff models. In: Duan, Q., Sorooshian, S., Gupta, H., Rosseau, H., Turcotte, R. (Eds.), Calibration of Watershed Models, Water Science and Applications 6, AGU, pp. 239-254.

Kouwen, N., Garland, G., 1989. Resolution considerations in using radar rainfall data for flood forecasting. Canadian Journal of Civil Engineering 16, 279-289.

Kull, D.W., Feldman, A.D., 1998. Evolution of Clark's unit graph method to spatially distributed runoff. Journal of Hydrologic Engineering 3 (1), 9-19.

Loague, K., 1990. R-5 Revisited 2. Reevaluation of a quasiphysically based rainfall-runoff model with supplemental information. Water Resources Research 26 (5), 973-987.

Loague, K.M., Freeze, R.A., 1985. A comparison of rainfall-runoff modeling techniques on small upland catchments. Water Resources Research 21 (2), 229-248.

Michaud, J., Sorooshian, S., 1994. Comparison of simple versus complex distributed runoff models on a midsized semiarid watershed. Water Resources Research 30 (3), 593-605.

Miller, D.A., White, R.A., 1999. A Conterminous United States multi-layer soil characteristics data set for regional climate and hydrology modeling, Earth Interactions, 2, available at http:// EarthInteractions.org.
Moore, I.D., Grayson, R.B., 1991. Terrain-based catchment partitioning and runoff Prediction using vector elevation data. Water Resources Research 27 (6), 1177-1191.

Naden, P.S., 1992. Spatial variability in flood estimation for large catchments: the exploitation of channel network structure. Hydrological Sciences Journal 37 (1), 53-71.

Neuf, F., 1981. Can we model the rainfall-runoff process today? Hydrological Sciences Bulletin 26 (3), 281-289.

Obled, C.H., Wendling, J., Beven, K., 1994. The sensitivity of hydrological models to spatial rainfall patterns: an evaluation using observed data. Journal of Hydrology 159, 305-333.

Ogden, F.L., Julien, P.Y., 1994. Runoff model sensitivity to radar rainfall resolution. Journal of Hydrology 158, 1-18.

Reed, S., Koren, V., Zhang, Z., Smith, M., Seo, D.-J., 2002. Distributed modeling for improved NWS river forecasts, Proceedings of the Second Federal Interagency Hydrologic Modeling Conference, Las Vegas, NV,

Rinaldo, A., Vogel, G.K., Rigon, R., Rodriguez-Iturbe, I., 1995. Water Resources Research 31 (4), 1119-1127.

Robinson, J.S., Sivapalan, M., 1995. Catchment-scale runoff generation model by aggregation and similarity analysis. In: Kalma, J.D., Sivapalan, M. (Eds.), Scale Issues in Hydrological Modeling, Wiley, New York, pp. 311-330.

Rukovodstvo po Hidrologicheskim Prognosam (Manual on Hydrological Forecasting), 1989, Kratkosrochniy prognoz raschoda i urovnay vody na rekach (Short-term forecast of river discharge and stage) vol. 2, Gidrometeoizdat, St. Petersburg Russia (in Russian).

Schumann, A.H., 1993. Development of conceptual semi-distributed hydrological models and estimation of their parameters with the aid of GIS. Journal of Hydrological Sciences 6, 519-528.

Seo, D.-J., Breidenbach, J.P., 2002. Real-time correction of spatially nonuniform bias in radar rainfall data using rain gauge measurements. Journal of Hydrometeorology 1, 222-240.

Seo, D.-J., Koren, V., Cajina, N., 2003. Real-time variational assimilation of hydrologic and hydrometeorological data into operational hydrologic forecasting, Journal of Hydrometeorology, 3, 627-641.

Seyfried, M.S., Wilcox, B.P., 1995. Scale and the nature of spatial variability: field examples having implications for hydrologic modeling. Water Resources Research 31 (1), 173-184.

Singh, V.P., 1996. Kinematic Wave Modeling in Water Resources, Surface-Water Hydrology. Wiley, London.

Skahill, B.S., Johnson, L.E., 1999. Evaluation of Finite Difference Methods for a Distributed Rainfall-Runoff Model. NOAA Technical Memorandum ERL FSL-23, Forecast System Lab., Boulder, CO.

Smith, A.A., 1980. A generalized approach to kinematic flood routing. Journal of Hydrology 45, 71-89.

Smith, M.B., Laurine, D., Koren, V., Reed, S., Zhang, Z., 2003. Hydrologic model calibration in the National Weather Service. In: Duan, Q., Sorooshian, S., Gupta, H., Rosseau, A., Turcotte, R. (Eds.), Calibration of Watershed Models, Water Science and Applications, 6, AGU, pp. 133-152. 
Strahler, A.N., 1957. Quantitative analysis of watershed geomorphology. Transactions of the American Geophysics Union 38, 913-920.

Sylvestre, J., Sylvestre, P., 2002. FLDWAV application: transitioning from calibration to operational mode, Proceedings of the Second Federal Interagency Hydrologic Modeling Conference, Las Vegas, NV.

Tokar, A.S., Johnson, P., 1995. Optimization of river characteristics in the Blue Nile watershed; Technical Note 121. In: Koren, V., (Ed.), NFS 3.0 Reference Manual, US Department of Commerce, NOAA, Silver Spring, MD.

Vieux, B.E., Moreda, F.G., 2003. Ordered physics-based parameter adjustment of a distributed model. In: Duan, Q., Sorooshian, S., Gupta, H., Rosseau, H., Turcotte, R. (Eds.), Calibration of Watershed Models, Water Science and Applications, 6, AGU, pp. 267-282.

Wang, M., Hjelmfelt, A.T., Garbrecht, J., 2000. DEM aggregation for watershed modeling. Journal of the American Water Resources Association 36 (3), 579-584.

Watson, F.G.R., Grayson, R.B., Vertessy, R.A., McMahon, T.A., 1998. Large scale distribution modeling and the utility of detailed data. Hydrological Processes 12 (6), 873-888.

White, D., 1988. Grid-based application of runoff curve numbers. ASCE Journal of Water Resources Planning and Management $114(6), 601-612$.
Wigmosta, M.S., Vail, L.W., Lettenmaier, D.P., 1994. A distributed hydrology-vegetation model for complex terrain. Water Resources Research 30 (6), 1665-1679.

Wilcox, B.P., Rawls, W.J., Brakensiek, D.L., Wight, J.R., 1990. Predicting runoff from rangeland catchments: a comparison of two models. Water Resources Research 26 (10), 2401-2410.

Willemin, J.H., 2000. Hack's law: sinuosity, convexity, elongation, WRR 36 (11), 3365-3374.

Willgoose, G., Kuczera, G., 1995. Estimation of subgrid scale kinematic wave parameters for hillslopes. In: Kalma, J.D., Sivapalan, M. (Eds.), Scale Issues in Hydrological Modeling, Advances in Hydrological Processes, Wiley, London, pp. $227-240$.

Woolhiser, D.A., 1996. Search for physically based runoff modela hydrologic El Dorado? ASCE Journal of Hydraulic Engineering 122 (3), 122-129.

Young, C.B., Bradley, A.A., Krajewski, W.F., Kruger, A., 2000 Evaluating NEXRAD multisensor precipitation estimates for operational hydrologic forecasting. Journal of Hydrometeorology 1, 241-254.

Zhang, Z., Koren, V., Smith, M., Reed, S., Wang, D., 2004. Use of NEXRAD data and basin disaggregation to improve continuous hydrograph simulations. Journal of Hydrologic Engineering 9 (2) $103-115$. 